\title{
Morphology of autogenous bone graft and castor oil polyurethane in the infraorbital rim of rabbits: a comparative study ${ }^{1}$
}

\author{
Estudo morfológico comparativo do enxerto ósseo autógeno e polímero de mamona \\ em rebordo infra-orbitário de coelhos
}

\author{
José Carlos Garcia de Mendonça ${ }^{2}$, Rafael De Rossi ${ }^{3}$, Celso Massaschi Inouye ${ }^{4}$, Diego Rodrigo Paulillo Bazan ${ }^{5}$, João \\ Carlos Castro Monteiro ${ }^{5}$, Juliana Pedroso de Mendonça ${ }^{6}$
}

1. Research perfomed at Multinstitutional Graduate Program in Health Sciences - Central West Agreement (Convênio Rede Centro Oeste, UnB, UFG and UFMS), Mato Grosso do Sul, Brazil.

2. Coordinator, Residency Program in Oral and MaxilloFacial Surgery, University Hospital, Federal University of Mato Grosso do Sul (UFMS), Brazil.

3. Associate Professor, Veterinary Medicine, UFMS, Brazil.

4. Full Professor, Department of Surgical Clinic, School of Medicine, UFMS, Brazil.

5. Resident, Oral and Maxillofacial Surgery, School of Medicine, UFMS, Brazil.

6. Dentist Surgeon, Volunteer at the Oral and Maxillofacial Surgery Program, University Hospital, UFMS, Brazil.

\begin{abstract}
Purpose: Morphological study comparing castor oil polyurethane and autogenous bone graft to repair bone defect in zygomatic bone of rabbits. Methods: Twenty-four adult, male New Zealand rabbits were randomly distributed between two groups of twelve. Bone defects of $5 \mathrm{~mm}$ in diameter were cut through the zygomatic bone and filled with polyurethane discs in the experimental group or autogenous bone harvested from the tibia in the control group. Animals were sacrificed after 30, 60 or 90 days, and the zygomatic bones were macro- and microscopically analyzed. Student's, Fisher's, chi-squared and McNemar's tests were used for statistical analysis. Results: Both the castor oil polyurethane and the autograft adapted well to the defect, with no need for fixation. Fibrous connective tissue encapsulated the polyurethane, but no inflammation or giant cell reaction was observed. Acidophilic and basophilic areas were observed inside the micropores of the polyurethane, suggesting cell nuclei. After 90 days, bone repair with a lamellar pattern of organization was observed in the control group. Conclusion: The castor oil polyurethane was biocompatible and did not cause inflammation. It may be considered an alternative to fill bone defects.
\end{abstract}

Key words: Biocompatible Materials. Bone Transplantation. Castor Oil. Rabbits.

\section{RESUMO}

Objetivo: Estudo morfológico comparativo do implante de poliuretana de mamona e enxerto ósseo autógeno em defeito ósseo padrão em osso zigomático de coelhos. Métodos: Vinte e quatro coelhos Nova Zelândia, machos, adultos, foram distribuídos aleatoriamente em dois grupos de 12. Defeitos de $5 \mathrm{~mm}$ de diâmetro, perenes, foram confeccionados em osso zigomático e preenchidos com discos pré-fabricados de poliuretana no grupo experimento ou osso autógeno extraído da tíbia no grupo controle. Os animais foram sacrificados após 30, 60 e 90 dias e as peças anatômicas foram avaliadas macro e microscopicamente. Foram utilizados os testes de Student, Fisher,qui-quadrado e McNemar para a análise estatística dos resultados. Resultados: A poliuretana e o osso autógeno se adaptaram ao defeito sem necessidade de fixação. Houve formação de tecido conjuntivo fibroso envolvendo a poliuretana, sem reação inflamatória ou presença de células gigantes. Verificaram-se áreas acidófilas e basófilas nos poros do material implantado, sugestivas de núcleos celulares. No grupo controle, observou-se aos 90 dias o reparo ósseo de padrão lamelar clássico. Conclusão: A poliuretana de mamona foi biocompatível e não causou reação inflamatória deletéria. Pode ser uma alternativa para o preenchimento de defeitos ósseos. Descritores: Materiais Biocompatíveis. Transplante Ósseo. Óleo de Rícino. Coelhos.

\section{Introduction}

Bone tissue has various mechanical properties and can regenerate spontaneously; however, this ability is limited. The repair of large bone defects still relies largely on autogenous bone graft, which is considered the gold standard of bone grafting ${ }^{1,2}$. Successful bone graft incorporation depends on close contact with the recipient bed, osteoprogenitor cell proliferation, osteoblast differentiation, osteoconduction and the biomechanical properties of the graft ${ }^{3,4}$. Peterson et al. ${ }^{2}$ reported that only autogenous bone grafts can provide living and histocompatible cells, which are essential to osteogenesis. There is evidence that proteins found in bone (bone 
morphogenetic protein - BMP), as well as growth factors may induce mesenchymal cell differentiation into osteoblasts in subjacent soft tissues of the recipient bed ${ }^{3,5}$. Autogenous bone is compatible with bone tissues and does not cause adverse tissue reaction ${ }^{6,7}$. Autogenous bone grafting, however, presents several difficulties such as size of the donor site; risk of donor site infection; severe resorption (around 35\%); difficulties in the treatment of patients ${ }^{6,8,9,10}$, mainly those with limited supply of autogenous bone (children, elderly patients) or patients who have used this supply in previous surgeries; prolonged time in the operating room; higher risk of morbidity and mortality ${ }^{3,6,8}$. Allografts and xenografts have considerable disadvantages ${ }^{3,4}$, and are not as successful as autografts ${ }^{3,11}$. Biomaterials can be used for the repair of segmental bone defects. These materials are relatively inert and some have variable resorption rates (phagocytosis, hydrolysis) ${ }^{12}$. Biocompatibility is the major obstacle regarding the use of these materials ${ }^{4}$. Among biomaterials, castor oil polyurethane - a polymer obtained from the castor-oil plant (Ricinus communis) - presents low residue content and variations in physical structure, which affect resistance, density, consistency and porosity, and therefore osteoconduction. Castor oil polyurethane has a molecular formula that has proved compatible with living tissues because of its physicochemical properties ${ }^{1,4,13}$. Castor oil polyurethane is commercially available in two separate bottles, one containing polyol $(\mathrm{OH})$ and the other containing a prepolymer (NCO). Both should be mixed with calcium carbonate to make the final product more porous and radiopaque ${ }^{1,4}$. The polymerization reaction is slightly exothermic (around $40^{\circ} \mathrm{C}$ ); an "adhesive state" is observed within 3-5 minutes, and a "malleable state" (biomass) within 5-10 minutes. It takes around 20 minutes for complete solidification, and the material obtained resembles hardened plastic. No free radicals ( $\mathrm{OH}$ and/or NCO) are present in the final polymerization product. The polymerization of the compound in or out of the recipient site may result in important differences in graft incorporation ${ }^{1,4,14}$. The purpose of this study was to compare castor oil polyurethane (with specific manufacture and application) and autogenous bone graft, which is considered the gold standard of bone grafting ${ }^{1}$, to repair a bone defect.

\section{Methods}

This study was approved by the Animal Ethics Committee of the Federal University of Mato Grosso do Sul (protocol 36/20020), and is in accordance with the ethical principles adopted by the Brazilian College of Animal Experimentation. A total of $24 \mathrm{New}$ Zealand rabbits were used (Oryctolagus cuniculus). Said animals were isogenic, albinic, male, aged 3 to 6 months, and weighed on average $2.6 \mathrm{Kg}$. The animals were donated by the laboratory animal facility of the Federal University of Mato Grosso do Sul (UFMS). The rabbits were randomly distributed between two groups of 12 each: Group I (experimental) and Group II (control). Each group was then randomly subdivided into three subgroups, with four animals each, according to the observation periods of 30 (I-30, II-30), 60 (I-60, II-60) or 90 days (I-90, II-90).
Preanesthesia and anesthesia were based on the recommendations of the School of Veterinary Medicine of UFMS, as well as the choice of drugs and dosage. Shaving was only performed after animals had been anesthetized. The eye on the side to be operated was protected using gentamicin ophthalmic ointment. Then, antisepsis with $2 \%$ iodine was performed and drapes were used to create a sterile field. Tarsorrhaphy for corneal protection followed, using 5-0 nylon monofilament suture. An incision was made in the skin and subcutaneous tissue below the lower eyelid, along the zygomatic arch, which was exposed by means of blunt dissection. Then an incision was made in the periosteum, which was detached from the bone at the infraorbital rim. The inferior periorbita was lifted and the lateral cortex of the zygomatic bone was exposed (Figure 1). Using a trephine of $4.25 \mathrm{~mm}$ in internal diameter and $5.00 \mathrm{~mm}$ in external diameter, under copious irrigation with isotonic saline solution $(0.9 \%)$, a circular bone defect was created in the middle line of the zygomatic arch. This defect went through the bone, producing a hole of $5.0 \mathrm{~mm}$ in diameter (Figures 2, 3 and 4). In animals of Group I, the defect created in the left orbit was filled with a disc of castor oil polyurethane previously manufactured and sterilized with ethylene oxide. Said disc was $5.00 \mathrm{~mm}$ in diameter and $3.00 \mathrm{~mm}$ in height, and adjusted to the defect perfectly, with no need for graft fixation (Figure 5). Suture of the muscular layer followed, with interrupted stitches (buried knots), using 40 nylon monofilament suture. A continuous subcuticular suture was placed (subcutaneous tissue and skin) using 60 nylon monofilament suture. Then, the surgical wound was cleaned with isotonic saline solution (0.9\%) and topical antibiotic was applied (rifamycin). The wound was not covered (Figure 6). Group II animals underwent the same surgical procedure previously described. However, the bone defect in these animals was created in the right orbit and filled with an autograft obtained from the right tibia. The graft was kept in isotonic saline solution (0.9\%) while the recipient site was prepared. During the study, the animals were kept at the laboratory animal colony of UFMS in metal cages. They were fed with suitable feed and had water ad libitum. Prior to the surgical procedure, the animals were weighed and their weights were recorded on a form. No complications caused by anesthesia or the surgical procedure were observed, and the animals recovered reflex and voluntary movements soon after the procedure. Up to the third day, movement was apparently painful to the animals of Group II. One week after the surgical procedure, two animals of Group II were sacrificed because they had suffered open fracture of the tibia. The two rabbits were replaced with two other animals of similar characteristics. After the observation periods of 30, 60 and 90 days, the animals were submitted to anesthesia again (with the same drug and dosage used before), and euthanized with an intramuscular injection of pentobarbital sodium (dose of $50 \mathrm{mg} / \mathrm{kg}$ ). The zygomatic bones were exposed and removed intact, after dissection of the adjacent soft tissues. Then, they were individually immersed in hermetic containers with $10 \%$ buffered formaldehyde solution and sent to the Anatomic Pathology Division, Department of Pathology of UFMS. Specimens were routinely processed for histopathological analysis, and stained with hematoxylin 
and eosin. Student's t-test, chi-squared test or Fisher's exact test and McNemar's test were used for statistical analysis of

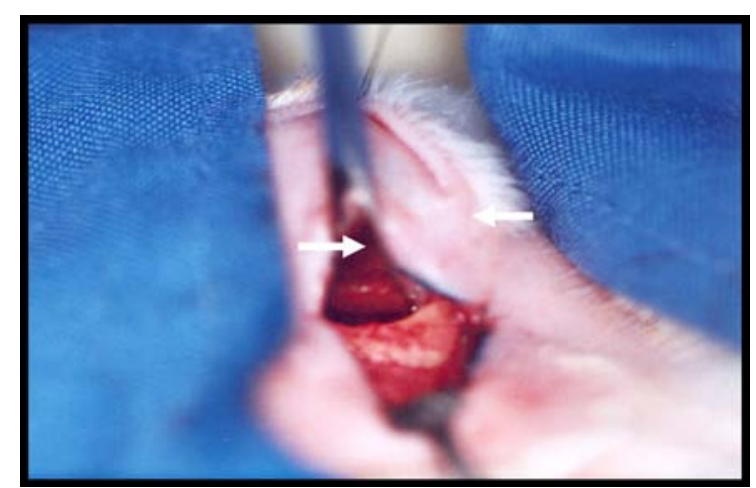

FIGURE 1 - Exposure of lateral cortical bone the infraorbital rim (arrows)

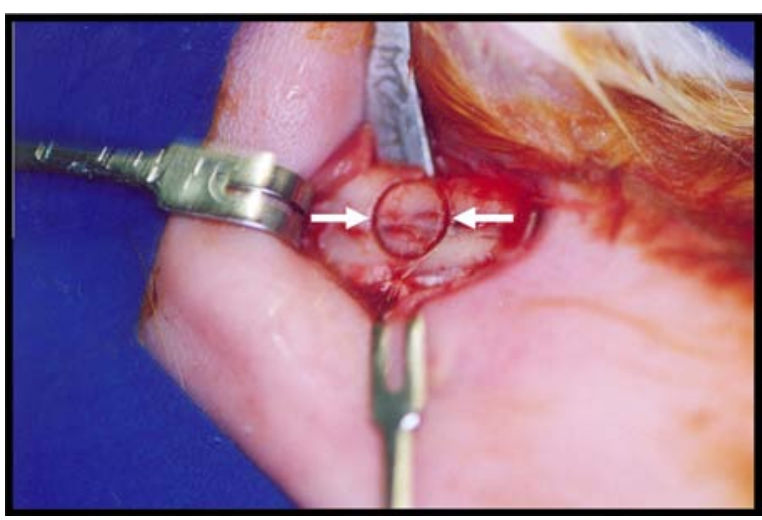

FIGURE 3 - Osteotomy after the use of a trphine (arrows)

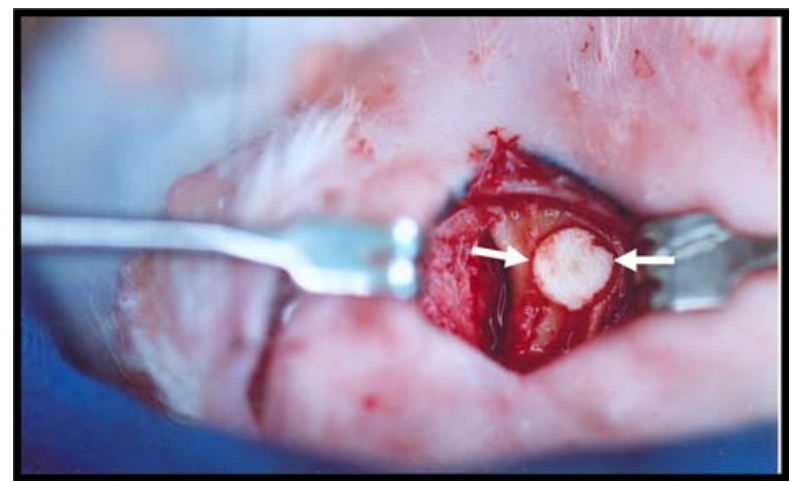

FIGURE 5 - Polyurethane graft adapted and adjusted without fixation (arrows)

\section{Results}

Some animals of Group II lost weight (Table 1), as expected, possibly due to greater surgical stress and immediate loss of movement. In subgroups I-30, I-60 and I90 , fibrous connective tissue could be macroscopically observed surrounding the castor oil polyurethane and the interface between bone and polyurethane. This tissue was observed as a capsule whose thickness increased with time. The graft was clearly visible (Table 2) and well-adapted the results. In all tests, statistical significance was set at $0.05 \%$, and an asterisk was used to indicate significant values.

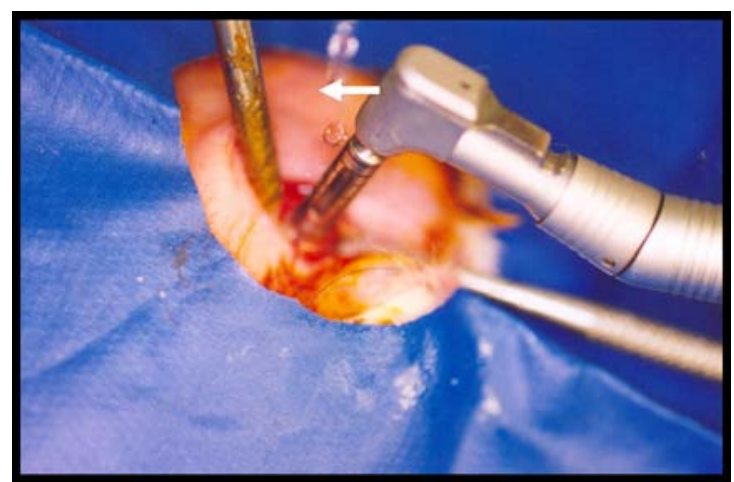

FIGURE 2 - Creation of bone defect with a treof phine (arrow)

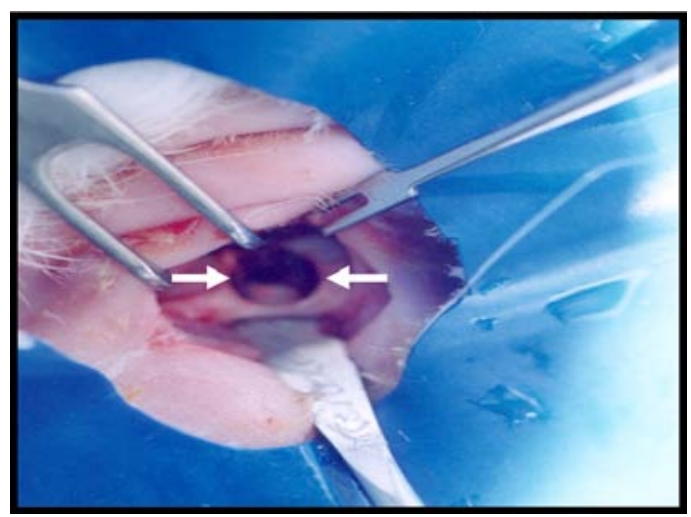

FIGURE 4 - Standard bone defect (arrows)

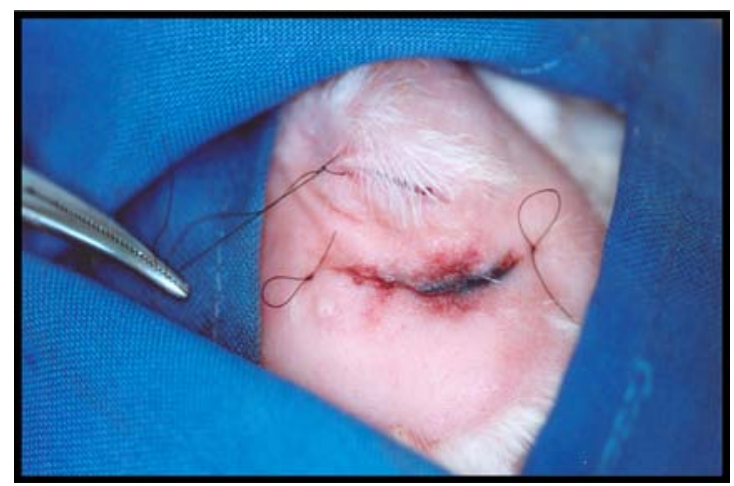

FIGURE 6 - Continuous subcuticular suture using 6.0 monofilament suture

(Table 3), with a porous appearance (Figure 7). Graft displacement was observed in only one animal, which was probably due to eyeball movement caused by the action of the extrinsic muscles of the eye. Microscopic examination of Group I specimens showed that the polyurethane graft was surrounded by a capsule of well-organized, dense, fibrous connective tissue, with no inflammation or foreign body giant cell reaction. This was observed at 30, 60 and 90 days (Figures 8 and 9). In subgroup I-30, degenerate erythrocytes were observed inside the pores of the graft. 
TABLE 1 - Initial and final weight (in grams) of animals from Groups I and II

\begin{tabular}{|c|c|c|c|c|c|c|}
\hline & \multicolumn{3}{|c|}{ GROUP I } & \multicolumn{3}{|c|}{ GROUP II } \\
\hline & Initial & Final & $\Delta$ & Initial & Final & $\Delta$ \\
\hline & 2980 & 3103 & 123 & 2910 & 2747 & -163 \\
\hline & 2370 & 2353 & -17 & 2240 & 2460 & 220 \\
\hline & 2866 & 2911 & 45 & 2726 & 2558 & -168 \\
\hline & 2858 & 2884 & 26 & 3286 & 3383 & 97 \\
\hline & 3230 & 3872 & 642 & 2820 & 2546 & -274 \\
\hline & 2421 & 2710 & 289 & 2320 & 2607 & 287 \\
\hline & 2670 & 3790 & 1120 & 2791 & 2945 & 154 \\
\hline & 2085 & 3081 & 996 & 3336 & 3639 & 303 \\
\hline & 1666 & 2270 & 604 & 2944 & 3278 & 334 \\
\hline & 2391 & 3263 & 872 & 2625 & 3070 & 445 \\
\hline & 2148 & 2379 & 231 & 3041 & 3435 & 394 \\
\hline & 2317 & 3273 & 956 & 2903 & 3523 & 620 \\
\hline Average & 2500.2 & 2990.75 & 490.58 & 2828.5 & 3015.92 & 187.42 \\
\hline SD & 438.43 & 521.09 & 422.61 & 329.71 & 427.62 & 271.91 \\
\hline
\end{tabular}

Student's $t$-test for two samples

(Group I x Group II - Initial weight)

calculated $t$ value $=2.0731 *$

critical $t$ value $=2.073875$

TABLE 2 - Macroscopic observation of the cortical bone of the infraorbital rim in animals of Groups I and II (30, 60 and 90 days), respectively

\begin{tabular}{llll}
\hline & \multicolumn{2}{c}{ Presence of cortical bone } & \\
\cline { 2 - 3 } & Yes & No & Total (\%) \\
\hline Polyurethane & 12 & 0 & $12(100.00)$ \\
Autograft & 7 & 5 & $12(58.33)$ \\
\hline Total & 19 & 5 & $24(79.16)$ \\
\hline
\end{tabular}

Fisher's exact test

calculated p value $=0.05590 *$

critical $\mathrm{p}$ value $=0.05$

TABLE 4 - Microscopic observation of acidophilic areas which suggest the presence of organic matter inside the pores of the castor oil polyurethane in animals of Group I (60 and 90 days, respectively)

\begin{tabular}{lccc}
\hline Polyurethane & \multicolumn{2}{c}{$\begin{array}{c}\text { Areas suggesting the } \\
\text { presence of organic matter }\end{array}$} & \\
\cline { 2 - 3 } & Present & Absent & Total (\%) \\
\hline 60 & 1 & 3 & $4(25)$ \\
90 & 2 & 2 & $4(50)$ \\
\hline Total & 3 & 5 & $8(37.5)$ \\
\hline
\end{tabular}

McNemar's test

calculated $\mathrm{x}^{2}$ value $=0.57143^{*}(\mathrm{p}=0.47)$

critical $\mathrm{x}^{2}$ value $=3.8414(\mathrm{p}=0.05)$
TABLE 3 - Macroscopic observation of the adaptation of the polyurethane or autograft to the bone defect created in the infraorbital rim of animals from Groups I and II (30, 60 and 90 days), respectively

\begin{tabular}{lccl}
\hline Group & \multicolumn{2}{c}{ Adaptation } & \\
\cline { 2 - 3 } & Successful & Unsuccessful & Total (\%) \\
\hline Polyurethane & 11 & 1 & $12(91.66)$ \\
Autograft & 12 & 0 & $12(100.00)$ \\
\hline Total & 23 & 1 & $24(95.83)$ \\
\hline
\end{tabular}

Chi-squared test

calculated $\mathrm{x}^{2}$ value $=2.08696 *(\mathrm{p}=0.16)$

critical $\mathrm{x}^{2}$ value $=3.8414(\mathrm{p}=0.05)$

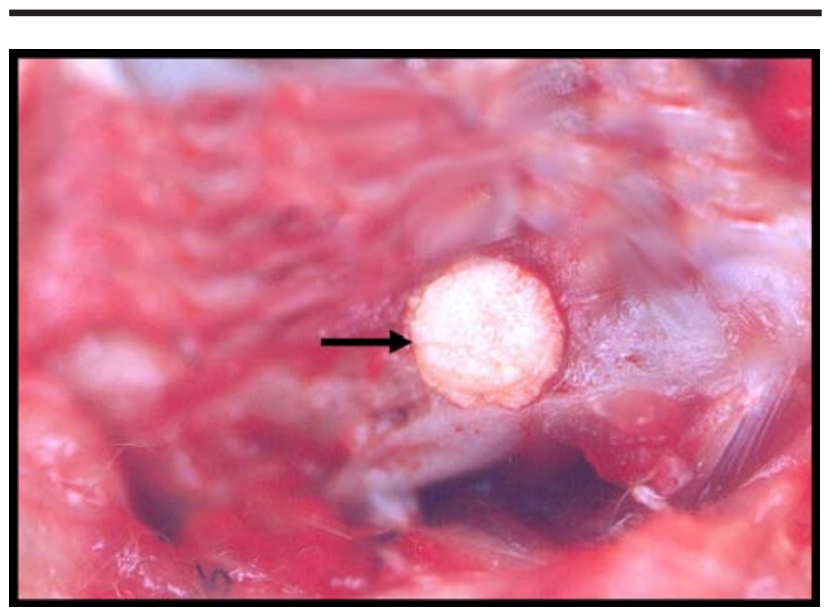

FIGURE 7 - Macroscopic aspect of the polyurethane graft at 30 days. Notice the material's porous surface (arrow) 
At 60 days, acidophilic areas were observed in the pores of the polyurethane in $25 \%$ of the animals. At 90 days, basophilic areas among acidophilic ones were observed in $50 \%$ of the animals, which suggested active cell nuclei synthesizing organic matter (Table 4 and Figures 10 and 11). In the control group, the cortical bone of the autograft could be macroscopically identified in 58\% of the animals (Figure 12). At 30 days, immature bone tissue, formed by bone trabeculae, could be microscopically observed at the interface between graft and bone. Osteocytes remained in the bone graft, which was being revascularized (Figure 13). At 60 days, mature bone tissue (lamellar bone) was observed, with vascular channels (Figure 14). At 90 days, complete bone repair was observed, and it was difficult to identify the cortical bone of the autograft. A lamellar pattern of organization was observed, with the aspect of compact bone.

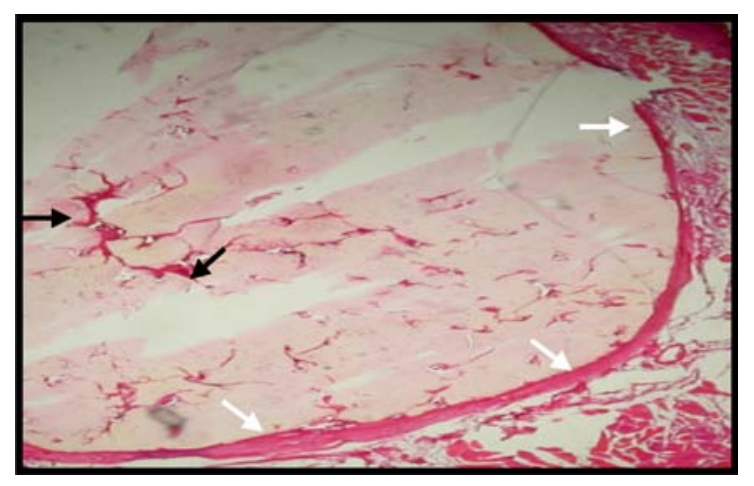

FIGURE 9 - Photomicrograph of the polyurethane at 60 days. Acidophilic areas inside the pores (black arrows) and a fibrous capsule with no inflammation can be observed (white arrows). HE, 100X.

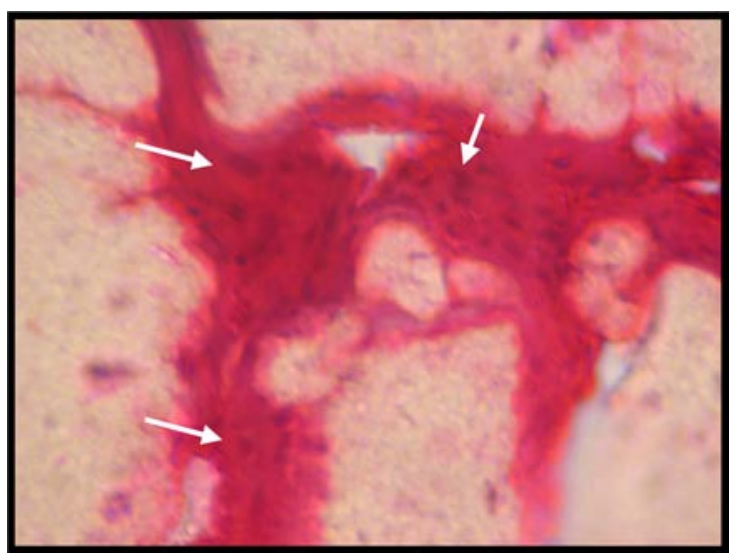

FIGURE 11 - Magnified photomicrograph of the previous picture. Basophilic structures can be observed among acidophilic ones (cell nuclei). HE, 400X.

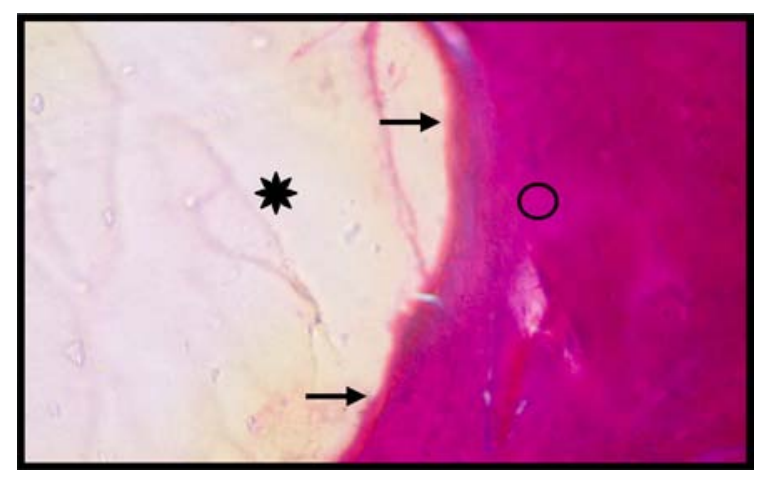

FIGURE 8 - Photomicrograph at 30 days. Notice the material's successful adaptation $(*)$ to the bone $\operatorname{defect}(\mathbf{O})$. HE, 100X.

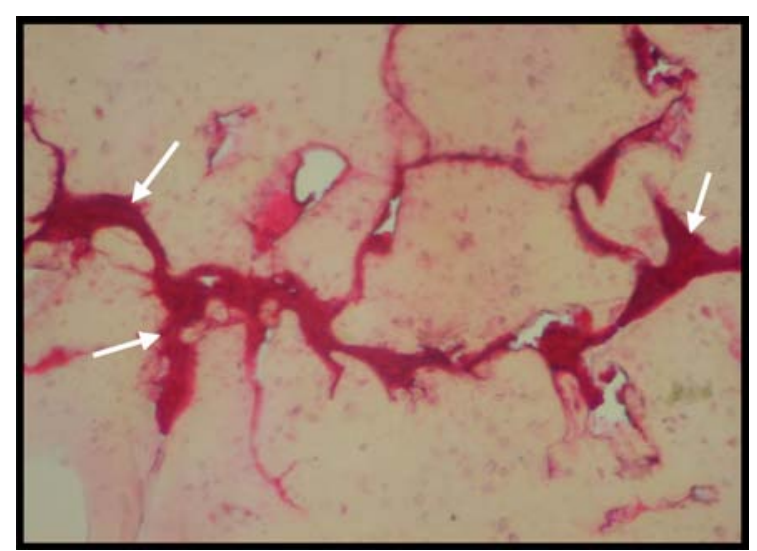

FIGURE 10 - Photomicrograph of the polyurethane at 90 days. Notice proliferation of connective tissue inside the pores (arrows). HE, 100X.

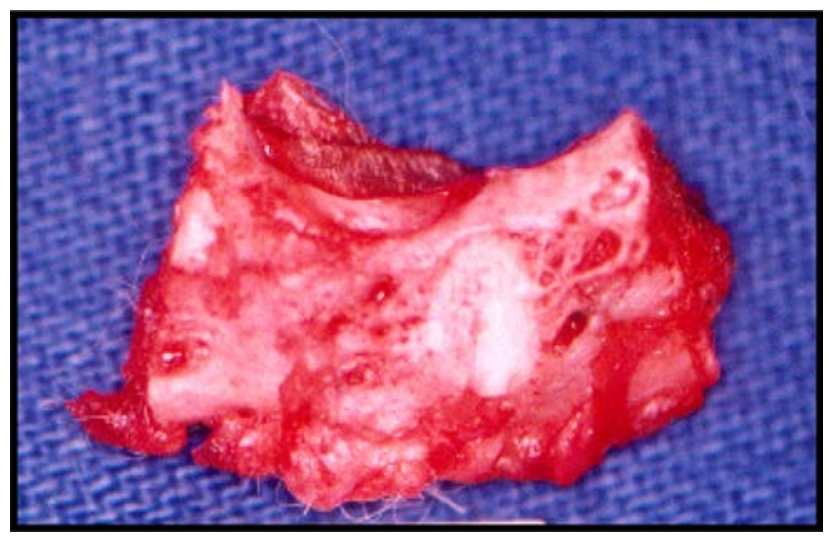

FIGURE 12 - Macroscopic aspect of autogenous bone graft at 60 days. Notice that cortical bone of the autograft is not easily identified (graft incorporation) 


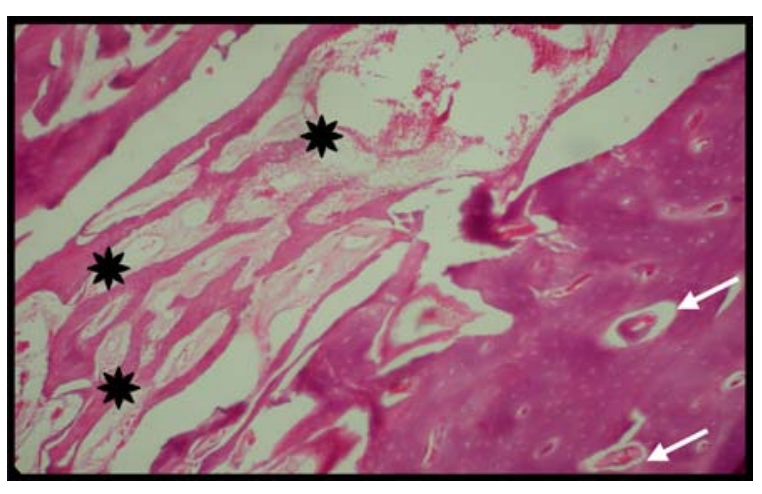

FIGURE 13 - Photomicrograph of bone graft at 30 days. Notice the presence of bone trabeculae the interface $(*)$ and revascularization of the bone graft (arrows). HE, 100X.

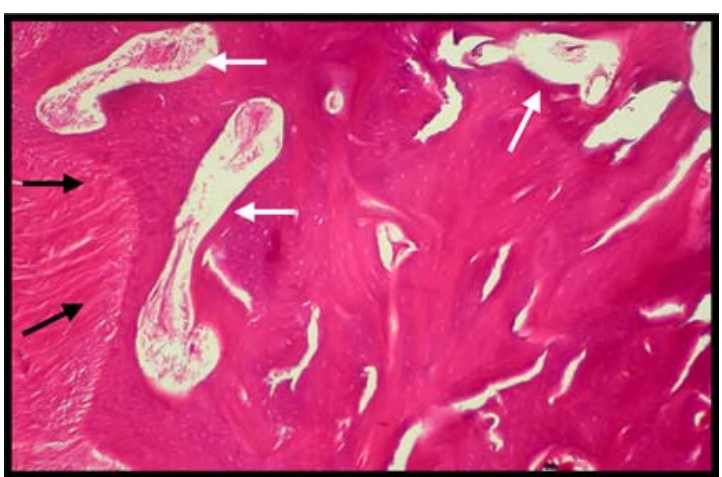

FIGURE 14 - Photomicrograph of bone graft at 90 days. Mature bone with vascular channels (white arrows); richness of collagenous fibers on the bone surface (black arrows). HE, 100X.

\section{Discussion}

Autogenous bone grafts are the best option to repair bone defects with decreased bone mass1. Autografts successfully integrate with surrounding tissues, are quite resistant and last long. Nevertheless, the limited supply of autogenous bone for the repair of defects is a disadvantage, and graft harvesting poses higher risks to the patient8,15. Different synthetic materials, allografts and xenografts have disadvantages with regard to application ${ }^{11}$, incorporation with surrounding tissues ${ }^{3,4}$, biocompatibility ${ }^{3,4,15}$, and resistance and/or durability ${ }^{9,10}$. Castor oil polyurethane has almost all the characteristics of an "ideal” biological material: biocompatibility ${ }^{4,13,16,17}$, osteoconductivity ${ }^{13,16}$, osseointegration ${ }^{4,13,16}$, resorption ${ }^{4,13,16}$, antimicrobial activity $^{5}$; it does not conduct heat or electricity ${ }^{16}$, and has many other physical properties. Bone defects generally have irregular shape and different volume. Premanufactured discs of castor oil polyurethane can be used to remodel areas with bone loss and repair the oral and maxillofacial skeleton. When comparing Groups I and II, macroscopic identification of the graft was significantly more frequent in the polyurethane group (Group I) than in the autograft group (Group II). This can be explained by the fact that the polyurethane is a lipid and thus slowly decomposed by lipolysis, according to cytochemical studies ${ }^{16}$. This enzymatic process occurs without the participation of giant cells, and is therefore a desired response in tissue regeneration. In the present study, the bone defects were completely filled with grafting material. No blood clots, which according to Buser et al. ${ }^{5}$ are important to promote new bone growth, were formed within the defect. Preserved osteoblasts in contact with the material were only present at the margins of the defect. This could explain why cortical bone formation ${ }^{6,7}$ was delayed in the experimental group. Microscopic observation revealed that no bone tissue was present at the interface between graft and bone in Group I animals (castor oil polyurethane), at the three observation periods. Only dense, fibrous connective tissue surrounding the material was observed. Bone tissue was present in all Group II animals (autogenous bone graft), and it matured

with time. We also noticed more acidophilic areas inside the autograft's pores and, at 90 days, there were basophilic areas among the acidophilic ones. This suggested the presence of active cell nuclei synthesizing organic matrix for future bone deposition similar to the natural process of intramembranous ossification ${ }^{5}$. The body isolates the grafted material (foreign body) by encapsulating it. The thickness of the fibrous layer is inversely proportional to the level of graft acceptance ${ }^{18}$. This study yielded results which were similar to those of Ohara et al. ${ }^{14}$ and Jacques ${ }^{1}$, who observed the same fibrous reaction encysting the grafted polyurethane. No severe inflammation or foreign body giant cell reaction was observed in the experimental group, when compared with the control group. This indicated great graft acceptance, which is in accord with the studies of Costa $^{19}$, Ignácio ${ }^{4}$ and Teixeira ${ }^{20}$. No author observed any kind of foreign body reaction to castor oil polyurethane, except for Vilarinho et al. ${ }^{17}$, who observed few inflammatory cells and some giant cells at 15 and 30 days in a study conducted with fragments of castor oil polyurethane (with and without calcium) grafted into the anterior chamber of the eye of mice. Despite the evidence suggesting that the polyurethane is resorbed, no resorption (partial or total) of the material occurred over the threemonth observation period. Further studies should be conducted in order to analyze the relationship between biomaterials and osteoinduction. Other variables that might modulate bone repair and contribute to graft incorporation such as drugs and hormones, as well as electrolytic, topical or systemic factors should also be investigated.

\section{Conclusions}

1. The grafted material was biocompatible, and can be considered an alternative for the repair of bone defects. The material did not cause inflammation or foreign body giant cell reaction. Instead, it was encapsulated by fibrous connective tissue. 
2. The premanufactured discs of polyurethane adapted to the bone defect perfectly, with no need for fixation.

3. Because castor oil polyurethane is a porous material, it can be vascularized and thus filled with connective tissue.

4. During the studied periods, no new bone formation was observed inside or on the surface of the grafted material.

5. Complete graft incorporation was not observed at the interface between the implant and bone.

\section{References}

1. Jacques JW. Estudo comparativo entre enxerto ósseo autógeno e poliuretana de mamona em coelhos [Mestrado].Universidade Federal de São Paulo; 2001.

2. Bôer HH. The history of bone grafts. Clin Orthop. 1988;226(A):292-8.

3. Peterson LR, Ellis E, Hupp JR, Tucker MR. Cirurgia oral e maxilo facial contemporânea. 3ed. Rio de Janeiro: Guanabara Koogan; 2000.

4. Ignácio H. Utilização do cimento derivado do polímero da mamona no preenchimento de falha óssea: estudo experimental em coelhos [Mestrado]. Ribeirão Preto: Universidade de São Paulo; 1995.

5. Buser D, Dahlin C, Schenk RK. Regeneração óssea guiada na implantodontia. Quintessense. 1996;2:31-46.

6. Psillaks JM. Cirurgia crânio-maxilo-facial: osteotomias estéticas da face. Rio de Janeiro: Medsi; 1987.

7. Zanine AS. Cirurgia e traumatologia buco-maxilo-facial. São Paulo: Revinter; 1990.

8. Younger EM, Chapman MW. Morbidity at bone graft donar sites. J Orthop Trauma. 1989;3:192-5.

9. Scales J. Tissue reaction to synthetic materials. Proc R Soc Med. 1953;46:647-9.

10. Holmes RE, Bucholz RY, Mooney V. Parous hydroxyapatite as a bone graft substitute in metaphyseal defects. J Bone Joint Surg. 1986;68:904-11.
11. Bolander ME, Bailian Q. The use of desmineralized bone matrix in the repair of segmental defects: angumentation with extracted matrix proteins and a comparison with autologous grafts. J Bone Joint Surg. 1986;68(A):1264-74.

12. Sailer HF, Pajorola GF. Cirurgia bucal. 1ed. São Paulo: Artes Médicas. 2000. p 213-316.

13. Karmandayan P. Observação sobre a superfície de interface entre osso e implantes de poliuretana com e sem carbonato de cálcio: estudo experimental em coelhos. [Tese]. Universidade Federal de São Paulo; 1997.

14. Ohara GH, Kojima KE, Rossi JC. Estudo experimental da biocompatibilidade do polímero de poliuretana vegetal da mamona. Acta Ortop. Bras.1995;3:62-8.

15. Stanley RB, Shih T. Construction of large fronto-orbital defects with dacron polyurethane custom prostyhesis and autogenous bone past. Plastic Reconst Surg. 1978;61:349-403.

16. Chierice GO. Pesquisa e desenvolvimento de biomateriais baseados em poliuretanas derivadas do óleo de mamona. SNM-PADCT-II; 1994.

17. Vilarinho RH, Hetem S, Ramalho, LTO. Implante de resina de poliuretana vegetal na câmara anterior do olho de camundongo. Odonto 2000. 1996;1:25-9.

18. Chavpil M. Zinc on other factors of the pharmacology of wound healing. In: Hunt TK. (editor). Wound healing and wound infection. New York: Aplleton CenturyCrafts; 1980. p.135-52.

19. Costa CAS, Marcantonio RAC, Hebling J, Teixeira HM. Biocompatibilidade do polímero de poliuretana vegetal derivada do óleo de mamona em estudo comparativo com cimento de óxido de zinco e eugenol. Odonto 2000. 1997;1:1:44-8.

20. Teixeira HM, Kuramae M, Ramalho LTO. Reação à resina vegetal de mamona sem bicarbonato de cálcio durante o processo de reparo em defeitos ósseos induzidos no corpo da mandíbula. Rev Odontol UNESP. 1999;23:1:63-72.

\section{Correspondence:}

José Carlos Garcia de Mendonça

Rua Vista Alegre, 505

79041-330 Campo Grande-MS Brazil

mendonca@nin.ufms.br
Conflict of interest: none Financial source: none

Received: April 07, 2006

Review: May 12, 2006

Accepted: June 16, 2006

\section{How to cite this article:}

Mendonça JCG, Rossi R, Inouye CM, Bazan DRP, Monteiro JCC, Mendonça JP. Morphology of autogenous bone graft and castor oil polyurethane in the infraorbital rim of rabbits: a comparative study. Acta Cir Bras. [serial on the Internet] 2006 Sept-Oct;21(5). Available from URL: http://www.scielo.br/acb. 